\title{
Ontogeny and reproductive functional morphology of the macroalga Wiartonella nodifera n. gen. n. sp. (Dasycladales, Chlorophyta) from the Silurian Eramosa Lagerstätte of Ontario, Canada
}

\author{
Steven T. LoDuca, ${ }^{1}$ and Denis K. Tetreault ${ }^{2}$ \\ ${ }^{1}$ Department of Geography and Geology, Eastern Michigan University, Ypsilanti, Michigan 48197, USA 〈sloduca@emich.edu〉 \\ ${ }^{2}$ Department of Earth and Environmental Sciences, University of Windsor, Windsor, Ontario N9B 3P4, Canada 〈deniskt@uwindsor.ca〉
}

\begin{abstract}
The thallus of a new noncalcified dasycladalean alga, Wiartonella nodifera n. gen. n. sp., from the mid-Silurian Eramosa Lagerstätte of Ontario, Canada, comprises a narrow main axis with laterals in whorls (euspondyl). Laterals branch to the second order and show a distinct expansion (node) at the termination of first-order lateral segments. Morphologic differences between specimens are interpreted as ontogenetic stages similar to those displayed by extant Dasycladales, including late-stage shedding of higher-order lateral segments. Examination of reproductive functional morphology using biophysical modeling indicates that the expanded terminations of the first-order lateral segments probably are not homologous with gametophores, and that reproduction instead was either endospore or cladospore, with details of the ontogenetic sequence pointing to the latter. The distinctive lateral morphology displayed by this species adds to the list of morphological innovation achieved by dasycladalean algae during a significant burst of evolutionary activity that unfolded between the Middle Ordovician and late Silurian.
\end{abstract}

\section{Introduction}

The mid-Silurian Eramosa Lagerstätte from the Bruce Peninsula region of Ontario, Canada, has yielded nonbiomineralized arthropods, lobopodians, and worms, and is one of only a few fossil deposits known worldwide to preserve soft parts of the conodont animal (Tetreault, 1995, 2001; von Bitter et al., 2007; Collette and Rudkin, 2010). Here, we describe a new, morphologically complex noncalcified macroalgal taxon from this exceptionally preserved biota. Abundant well-preserved material provides the basis for detailed studies of the ontogeny and reproductive functional morphology of this new taxon, interpreted herein as a member of the extant green algal order Dasycladales. Considered as such, it adds to a considerable list of noncalcified dasycladalean algae reported from Silurian strata in the last three decades, including material from New York (LoDuca, 1990, 1997), Wisconsin (LoDuca et al., 2003), Ontario (LoDuca, 1995, 1997), Arctic Canada (LoDuca et al., 2011), New Brunswick (LoDuca et al., 2013), Sweden (Kenrick and Vinther, 2006), and Estonia (Tinn et al., 2009, 2015; Mastik and Tinn, 2015).

\section{Geologic setting and age}

The Eramosa Lagerstätte is situated within the upper part of the Eramosa Formation, as defined by Brett et al. (1995), in the Bruce Peninsula region of Ontario. Most of the Eramosa Formation in this area is composed of well-bedded dolostone with occasional argillaceous intervals, but stromatoporoid-rich bioherms are locally developed (Armstrong, 1993; Tetreault, 2001). A Wenlockian age for this interval was reported by
Bancroft et al. (2016) based on conodont evidence and carbonate carbon-isotope stratigraphy.

In an overview of the Eramosa Lagerstätte provided by von Bitter et al. (2007), three biotas were recognized, each known only from a single limited geographic area in the southern part of the Bruce Peninsula. The macroalgal taxon described herein belongs to Biota 3 of that report, located in a quarry operated by Owen Sound Ledgerock Ltd. near Wiarton (locality D of von Bitter et al., 2007). All specimens of the new taxon occupy bedding plane surfaces of large blocks removed from the lowermost part of a small pit on the northeasternmost part of the quarry property, north of Oliphant Road. The stratigraphic section at this location and level comprises light gray dolostone beds 15 to $30 \mathrm{~cm}$ thick that alternate with laminated intervals 5 to $15 \mathrm{~cm}$ thick. Within the laminated intervals, individual beds range from less than 1 to nearly $10 \mathrm{~mm}$ in thickness and alternate between buff to light gray dolostone and dark gray to brown, organic-rich calcareous shale. All of the alga material described herein was recovered from the organic-rich calcareous shale layers. The thicker dolostone beds that separate the laminated intervals show graded bedding and include chaotically oriented brachiopods and coral heads (favositids). The entire section at this location has a gentle southward dip, the dip angle increasing updip and eventually flattening out downdip. This local irregularity likely reflects deposition along the flank of a large bioherm, in which case the alga-bearing sediments accumulated near the base of this structure because the blocks that produced the specimens were quarried from an area close to where the dip begins to level out. The bioherm itself at this location is not exposed, but similar flank beds and their associated bioherms are exposed in nearby roadcuts. 
In the main pit on the south side of Oliphant Road and located slightly lower stratigraphically is a further occurrence of Biota 3 of the Eramosa Lagerstätte (von Bitter et al., 2007). Noncalcified algae occur within this interval as well (Tetreault, 2001 ), in this case in association with a diverse array of nonbiomineralized animal taxa, but the algal taxon described herein has not been recovered from this occurrence, or from the other two biotas described by von Bitter et al. (2007).

\section{Paleoecology and taphonomy}

The new macroalgal taxon comprises part of a distinctive, low-diversity assemblage. Associated fossils are limited to scolecodonts, which often occur as paired assemblages without associated soft parts, orthoconic cephalopods, rhynchonellid brachiopods, high- and low-spired gastropods, rare eurypterids, and several additional noncalcified macroalgal taxa (Tetreault, 2001; Eriksson and von Bitter, 2015). Shelly material is sparse, and trace fossils are lacking. Because noncalcified macroalgae dominate the nonbiomineralized component of the biota, the Eramosa Lagerstätte at this stratigraphic level and location is an algal-Lagerstätte (sensu LoDuca et al., 2011).

Material of the new macroalgal taxon is the most abundant nonbiomineralized component of the biota and in most cases occurs as localized patches devoid of other taxa with the exception of brachiopods, which are preserved as faint, difficult to detect molds. Commonly, surfaces surrounding the algal patches are barren and, occasionally, specimens show alignment (Fig. 1.1, 1.2). Specimens with preserved rhizoids in some cases show this structure in contact with brachiopods (e.g., Fig. 2.1, 2.2), suggesting a preference for attachment to hard substrates. Small specimens typically retain the full complement of laterals, whereas large specimens are often surrounded by a halo of detached lateral segments (Fig. 1.1, 1.2).

Characteristics of the algal material noted above indicate essentially in-situ burial, and the associated sedimentology points to obrution during small-scale storm events, the thin layers of entombing sediment perhaps delivered by sediment gravity flows generated along the flanks of nearby bioherms. Collectively, the lack of bioturbation, preservation of nonbiomineralized material, and biotic composition indicate a poorly oxygenated, low-energy, shallow marine depositional environment. The patchiness of the algal material may have been controlled by the availability of brachiopod valves to serve as attachment sites, and nearby bioherms may have restricted circulation, thereby promoting development of dysoxic bottom waters.

Specimens of the new algal taxon are jet black and, when freshly exposed, are difficult to detect against the nearly equally dark matrix. Upon weathering, however, the fossils become apparent as the tone of the matrix lightens. Energy-dispersive X-ray spectroscopy (EDS) analyses indicate a carbonaceous composition for the algal material (Fig. 2.3). Interestingly, main axes and laterals are often essentially circular in cross-section (Figs. 2.3, 4.1, 4.2). Such three-dimensional preservation indicates particularly rapid lithification of the surrounding sediment following deposition.
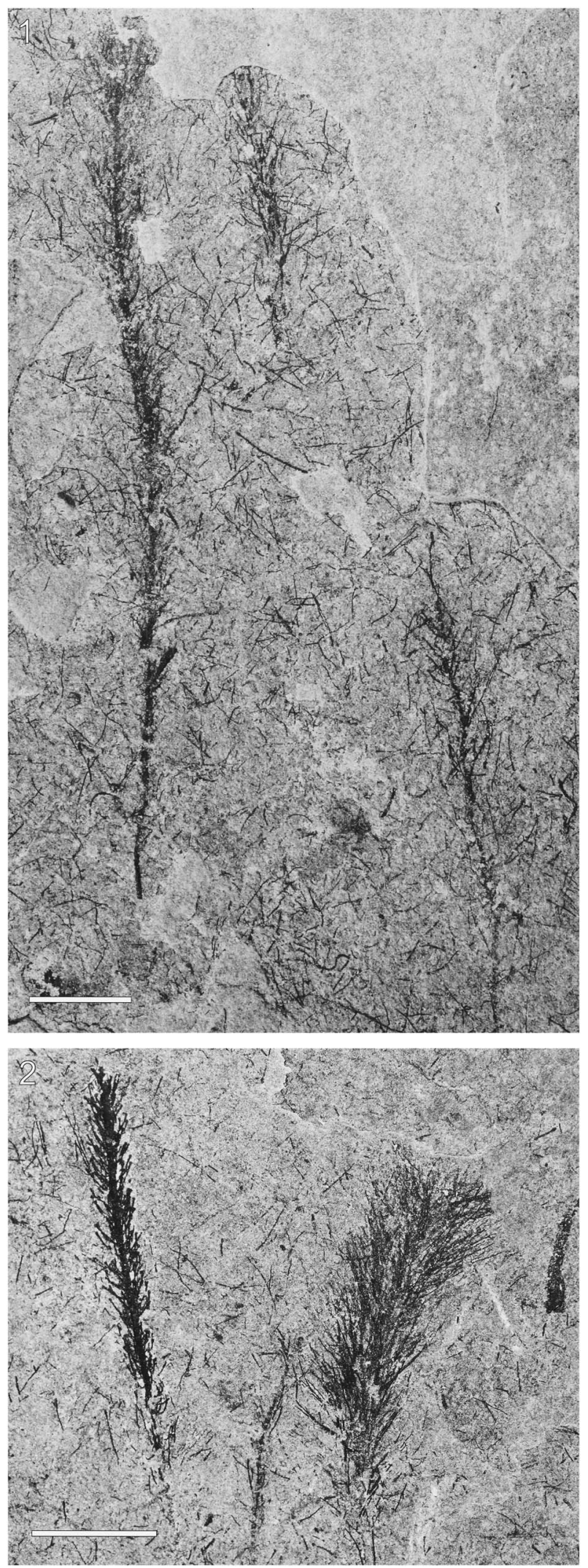

Figure 1. Wiartonella nodifera n. gen. n. sp. from the Silurian Eramosa Formation, Wiarton, Ontario: (1) thalli showing current alignment and surrounding localized accumulations of detached second-order lateral segments (ROM 63801); (2) thalli showing current alignment, specimen at left is surrounded by detached second-order lateral segments (ROM 63797). All specimens photographed dry in direct light. Scale bars represent $5 \mathrm{~mm}$. 


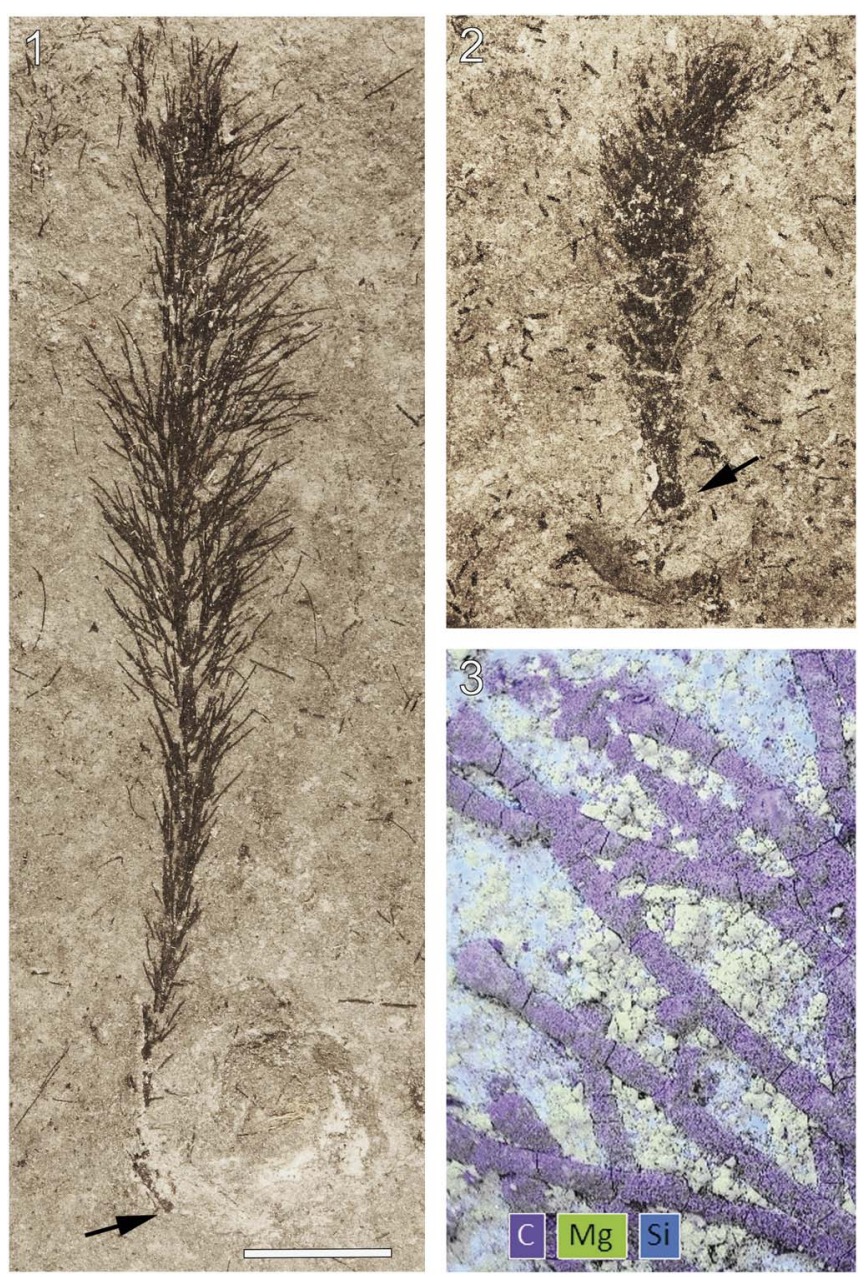

Figure 2. Wiartonella nodifera n. gen. n. sp. from the Silurian Eramosa Formation, Wiarton, Ontario: $(\mathbf{1}, \mathbf{2})$ thalli with holdfast (arrow) in contact with poorly preserved brachiopods (ROM 63793, ROM 63802). (3) Composite EDS elemental map of a part of ROM 63803 (arrow at lower left in 3.9). Scale bar is $(\mathbf{1}, \mathbf{2}) 5 \mathrm{~mm}$; (3) $0.33 \mathrm{~mm}$.

\section{Materials and methods}

The study material comprises some 30 slabs, most of which have multiple specimens distributed across the bedding plane surfaces. More than 60 specimens in total were examined. High-resolution morphometric data were collected from digital images using the open source program ImageJ.

Electron microscopic study of the material was conducted using a Hitachi S-3200N at the Electron Microbeam Analysis Laboratory, Department of Earth and Environmental Science, University of Michigan and an FEI Quanta 600F at the University of Missouri Electron Microscopy Core. All specimens were imaged uncoated under low vacuum, and backscattered electron images were obtained using an accelerating voltage of $15 \mathrm{keV}$. EDS elemental maps (University of Missouri) were collected uncoated under high vacuum with operating parameters as follows: $10.5 \mathrm{~mm}$ sample working distance, $15-\mathrm{keV}$ beam accelerating voltage, 4.0 beam spot size, 900 seconds live time.

Repository and institutional abbreviation.-Specimens used in this study are reposited at the Royal Ontario Museum (ROM).

\section{Systematic paleontology}

Order Dasycladales Pascher, 1931

Family Triploporellaceae (Pia, 1920) Granier and Bucur in Granier et al., 2012

Tribe Triploporelleae (Pia, 1920) Bassoullet et al., 1979

Subtribe Triploporellinae (Pia, 1920) Bassoullet et al., 1979 Genus Wiartonella new genus

Type species.—Wiartonella nodifera $\mathrm{n}$. sp., by monotypy.

Diagnosis.—As for type species, by monotypy.

Etymology.-In reference to the geographic origin of the material, near the town of Wiarton, Ontario, Canada.

Occurrence.-Known only from the Eramosa Formation exposed in the northernmost pit of the Owen Sound Ledgerock Ltd. quarry, $4 \mathrm{~km}$ northwest of Wiarton, Ontario.

Remarks.-The radially symmetrical thallus architecture of Wiartonella, comprising a central axis bearing laterals arranged in discrete whorls, is a common characteristic of dasycladalean algae, an extant order within the Chlorophyta that develops $\mathrm{cm}$-scale unicellular (siphonous) thalli. Outwardly similar thalli, however, are also produced by charophytes (see Feist et al., 2003), as well as by some red and brown algae, all of which are multicellular. It is not possible to determine from the specimens if Wiartonella thalli were siphonous, but details of the ontogenetic sequence, particularly the shedding of higher-order lateral segments (see below), point strongly to a dasycladalean affinity. However, because nothing is known for this taxon regarding chlorophyll composition or cellular-level organization, the possibility remains that Wiartonella belongs to a group of algae apart from Dasycladales for which there are no living representatives.

Wiartonella nodifera new species

Figures 1.1, 1.2, 2.1-2.3, 3.1-3.14, 4.1-4.4

Holotype.-ROM 63795 (Fig. 3.3, 3.4), Silurian, Eramosa Formation exposed in the northernmost pit of the Owen Sound Ledgerock Ltd. quarry, $4 \mathrm{~km}$ northwest of Wiarton, Ontario.

Diagnosis.-Noncalcified cylindrical to claviform thallus comprising a narrow, cylindrical, uniaxial, unbranched main axis with laterals in whorls (euspondyl). Laterals along lower part of thallus unbranched, hairlike. Laterals along upper part of thallus branched to the second order; first-order lateral segments cylindrical along most of length but with expanded terminations; second-order lateral segments produced in pairs from tips of first-order segments, long, slender, distally-tapered. Rhizoid short, stout.

Occurrence.-Known only from the type locality.

Description.-Thallus noncalcified, typically 3 to $6 \mathrm{~mm}$ wide and reaching $45 \mathrm{~mm}$ in height (ROM 63801.1; Fig. 1.1), comprising a 


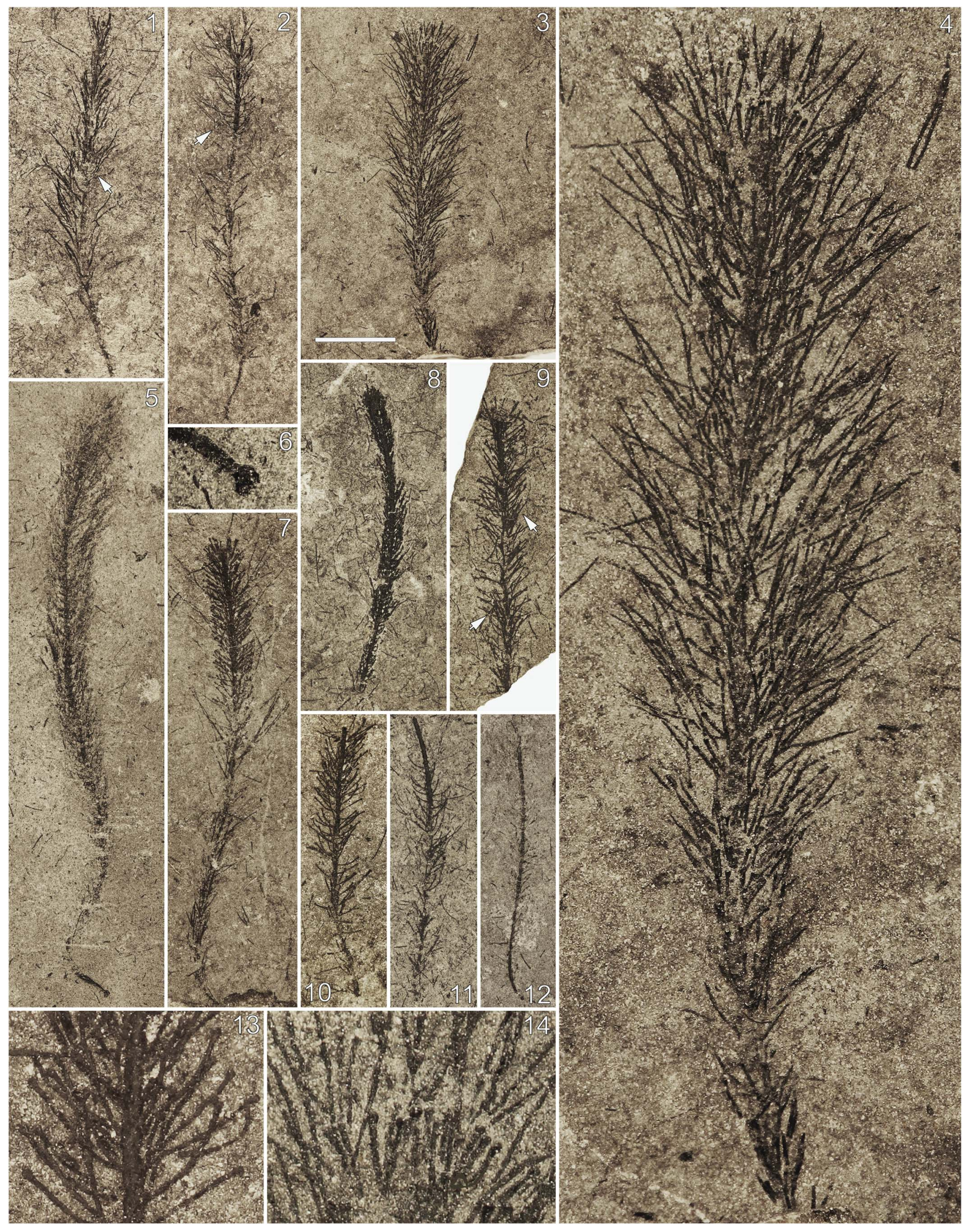


central main axis with laterals arranged in whorls and inclined relative to the main axis at an angle of $\sim 45^{\circ}$. Main axis of uniaxial construction, cylindrical, $\sim 0.3 \mathrm{~mm}$ wide, slightly expanded at whorl junctions, apex rounded (Figs. 3.13, 4.1). Holotype (ROM 63795 ) bears two distinct types of laterals. Laterals along lower part of main axis unbranched with tapered ends, $0.05 \mathrm{~mm}$ in diameter at mid-point of length and reaching a length of $1.3 \mathrm{~mm}$ (Fig. 3.3, 3.4). Laterals along upper part of thallus branched to the second order; first-order lateral segment cylindrical, $0.065 \mathrm{~mm}$ in diameter and $1.1 \mathrm{~mm}$ in length, with an expanded termination $0.11 \mathrm{~mm}$ in maximum diameter bearing from subtly faceted distal surfaces two slender elongate second-order segments $0.05 \mathrm{~mm}$ in diameter and $\sim 2 \mathrm{~mm}$ in length, these diverging from each other at an angle of $20^{\circ}$ to $30^{\circ}$ and tapering distally (Fig. 3.4, 3.14; Table 1). Spacing between adjacent whorls $\sim 0.5 \mathrm{~mm}$; lateral number per whorl $\sim 12$, this determined from first-order lateral tips visible in upper part of uppermost whorl (Fig. 3.14), the precise number uncertain because of overlapping laterals adjacent to main axis. Basal part of thallus unknown (beyond slab margin). Specimens ROM 63793, 63794, 63800, and 63804 similar to holotype, but details for branched laterals are more apparent in parts of 63800 and 63804 (Figs. 3.1, 3.2, 4.3, 4.4). Morphological variants include small thalli bearing only unbranched laterals (Fig. 2.2) and thalli lacking most or all second-order segments for the branched laterals (Figs. 1.2 [left specimen], 3.7-3.10, 4.2). Specimens ROM 63793, 63794, and 63802 show a short, stout rhizoid extending over a circular area roughly twice the diameter of the main axis (Figs. 2.1, 2.2, 3.5, 3.6).

Etymology.-The trivial name is in reference to the expanded terminations of the first-order segments of the branched laterals.

Materials.-ROM 63792-63804.

Remarks.-Wiartonella differs from all extant dasycladalean genera except Neomeris and Bornetella in that the laterals branch only to the second order. Bornetella develops gametophores along the sides of the first-order laterals, but in Neomeris the gametophores are borne along the tips of the first-order lateral segments, a position analogous to that occupied by the expanded terminations, or nodes, of the primary laterals in Wiartonella. A key difference, however, is that the second-order lateral segments of Wiartonella emerge directly from the tips of the nodes, whereas in Neomeris they clearly diverge from the first-order lateral segment and not the gametophore. Both of these genera differ significantly from Wiartonella in that the second-order laterals develop expanded portions that coalesce to form a cortex, and both develop calcification. It may be significant from a morphogenetic standpoint, however, that both genera include species that develop deciduous hairs from the cortex facets in a fashion roughly analogous to how the nodes of Wiartonella bear second-order laterals.

Among fossil genera, Wiartonella is similar in many respects to the noncalcified dasycladalean Kalania Tinn, Mastik, Ainsaar, and Meidla, 2015, known only from the type species, $K$. pusilla from the Llandoverian of Estonia. Both taxa are characterized by euspondyl lateral arrangement, primary laterals with a complex form (i.e., they are not simple cylinders), and elongate secondaries produced in pairs from the tips of the primaries. A key distinction, however, concerns the form of the primaries. Specifically, according to the diagnosis provided by Tinn et al. (2015, p. 209), those of Kalania are pyriform, gradually and continuously expanding distally, whereas the primaries of the new Canadian material are cylindrical along most of their length, expanding only at the end to form a bulbous terminal node. The distinctive form characteristic of the latter is sufficient to preclude assignment of the Canadian material to Kalania and comprises an essential element in the diagnosis of Wiartonella. A further key distinction according to the diagnosis provided by Tinn et al. (2015) is that gametophores are developed along the sides of the primaries of Kalania. Nothing comparable in this position, however, has been observed among the Canadian material. Rhabdoporella Stolley, 1893, a calcified taxon known from Ordovician and Silurian strata, is characterized by laterals with a form comparable to the first-order segments of the branched laterals of Wiartonella, but key differences here are that the laterals have an aspondyl as opposed to euspondyl arrangement and do not branch. The same distinctions apply to the Mesozoic calcified taxon Gyroporella Gümbel, 1872 (see Pia, 1920). Cyclocrinitids, a group of calcified algae well known from the Ordovician and Silurian, also share some key characteristics with Wiartonella, including general lateral form (both have laterals with distinctly inflated terminations) and, in this case, euspondyl lateral arrangement. All cyclocrinitid genera, however, develop a cortex. In addition, no cyclocrinitid genera are known to have produced secondaries with an elongate form, although it is possible that these were present in some species and not preserved because they extended beyond the zone of calcification. The same may apply to some Mesozoic calcified euspondyl taxa that lacked a cortex and are characterized by inflated primary laterals somewhat similar in form to those of Wiartonella, such as Uragiella Pia, 1925, Holosporella Pia, 1930 and Neogyroporella Yabe and Toyama, 1949 (see Barattolo et al., 2008). The Mesozoic calcified euspondyl taxa Triploporella Steinmann, 1880 and Petrascula Gümbel, 1873 are also characterized by inflated primary laterals, and here these bear secondaries as well. Both taxa differ from Wiartonella in details of the form of the primaries. In addition, the primaries of Triploporella typically bear three or four secondaries, as opposed to two in Wiartonella, and the laterals of Petrascula branch beyond the second order (see Bernier, 1979).

Figure 3. Wiartonella nodifera n. gen. n. sp. from the Silurian Eramosa Formation, Wiarton, Ontario. (1, 2) Nearly complete thalli with most second-order lateral segments attached to primary laterals, branching details for laterals marked by arrows are shown in 4.3 and 4.4, respectively (ROM 63804, 63800). $(3,4)$ Holotype, nearly complete thallus with most second-order lateral segments attached to primary laterals and detached pair of second-order lateral segments near top right of thallus (ROM 63795). (5) Complete thallus with full complement of attached second-order lateral segments and holdfast at base (ROM 63794). (6) Enlargement of holdfast for specimen shown in (5). (7-10) Thalli lacking all or most second-order lateral segments, areas marked by arrows in (9) are shown in detail in 2.3 and 4.2, respectively (ROM 63792, 63798, 63803, 63796.1). (11, 12) Thalli lacking most laterals (ROM 63799, 63796.2). (13) Enlargement of middle part of thallus shown in (10). (14) Enlargement of upper part of holotype showing uppermost whorl with two second-order lateral segments for each primary lateral segment and expanded terminations for the latter. All specimens photographed dry in direct light. Scale bar is (1-3, 5, 7-12) 5 mm; (4) 1.33 mm; (6) $1.2 \mathrm{~mm}$; (13) $1.25 \mathrm{~mm}$; (14) $0.715 \mathrm{~mm}$. 
Table 1. Morphometric data (in millimeters) for select specimens of Wiartonella nodifera. Values for $\mathrm{d}_{1}, \mathrm{l}_{1}, \mathrm{NodeD}_{2} \mathrm{~d}_{2}$, and $\mathrm{l}_{2}$ are averages of measurements taken from 10 different laterals on the same specimen; standard deviations in parentheses. $\mathrm{W}=$ thallus width at widest point; $\mathrm{H}=$ thallus height; $\mathrm{D}=$ main axis width; $L=$ main axis length; $d_{1}=$ width of first-order lateral segment (cylindrical portion); $1_{1}=$ total length of first-order lateral segment; NodeD = width of node at widest point; $\mathrm{d}_{2}=$ width of second-order lateral segment, measured at the mid-point of length; $1_{2}=1$ length of second-order lateral segment.

\begin{tabular}{|c|c|c|c|c|c|c|c|c|c|}
\hline Specimen & $\mathrm{W}$ & $\mathrm{H}$ & D & $\mathrm{L}$ & $\mathrm{d}_{1}$ & $1_{1}$ & NodeD & $\mathrm{d}_{2}$ & $l_{2}$ \\
\hline ROM 63792 & 6.5 & 27.0 & 0.33 & 25.6 & $0.069(0.007)$ & $1.4(0.09)$ & $0.11(0.004)$ & $0.042(0.004)$ & $3.4(0.22)$ \\
\hline ROM 63795 & 5.8 & 22.0 & 0.30 & 20.1 & $0.065(0.005)$ & $1.2(0.08)$ & $0.11(0.005)$ & $0.050(0.005)$ & $1.9(0.21)$ \\
\hline ROM 63800 & 4.1 & 26.5 & 0.31 & 23.4 & $0.060(0.009)$ & $1.1(0.08)$ & $0.10(0.003)$ & $0.041(0.005)$ & $2.1(0.11)$ \\
\hline ROM 63804 & 4.9 & 23.9 & 0.30 & 21.7 & $0.061(0.007)$ & $1.0(0.07)$ & $0.10(0.004)$ & $0.042(0.004)$ & $2.2(0.12)$ \\
\hline ROM 63796.1 & 3.5 & 17.0 & 0.30 & 17.0 & $0.075(0.008)$ & $1.5(0.05)$ & $0.12(0.004)$ & - & - \\
\hline ROM 63803 & 3.6 & 18.4 & 0.35 & 17.0 & $0.065(0.007)$ & $1.7(0.09)$ & $0.11(0.005)$ & - & - \\
\hline
\end{tabular}

The rhizoid of Wiartonella is unusual in relation to that of other Silurian dasycladalean taxa, such as Medusaegraptus and Chaetocladus, in being stout and somewhat wider than the main axis, rather than a simple tapered prone extension of the main axis (LoDuca, 1990, 1997). Its form, however, is not unlike that known for some living Dasycladales (e.g., Berger and Kaever, 1992, fig. 4.2c). Rhizoid form of $W$. nodifera may reflect attachment to hard substrates, as opposed to anchoring in soft mud, an inference supported by rhizoids observed in direct contact with brachiopod shells (Fig. 2.1, 2.2). The distinct morphological variants included within the species and the reproductive significance of the laterals are considered in detail in the sections below.

\section{Ontogeny}

Morphologic differences between the various specimens assigned to Wiartonella nodifera are interpreted herein as reflecting a complex ontogeny involving distinct stages. During the initial stage (stage 1) whorls of unbranched hairlike laterals were produced as the main axis commenced elongation (Figs. 2.2, 5.1). After at least five such whorls were produced, the thallus entered a markedly different growth stage (stage 2), during which numerous whorls of branched laterals were produced in succession, the hairlike second-order lateral segments emerging from distinctly expanded terminations of the firstorder lateral segments (Figs. 3.1-3.3, 5.2). Finally, late in the ontogenetic sequence (late stage 2), the second-order lateral segments were shed, resulting in thalli largely or entirely devoid of these structures (Figs. 3.7-3.10, 5.3).

Size data for the material is consistent with interpretation of stage 1 and stage 2 thalli as ontogenetic stages of a single species rather than distinct species. In particular, in terms of main axis length, the largest specimens interpreted as stage 2 thalli are larger than the largest of the stage 1 thalli by nearly a factor of two. That the second-order lateral segments of $W$. nodifera were shed as a natural part of the life cycle, as opposed to simply detached as a consequence of transport prior to burial, is indicated by two factors. First, thalli are known that retain all of the first-order segments but none of the second-order (e.g., Fig. 3.7-3.10). Second, some thalli are surrounded by haloes of detached secondorder lateral segments (Fig. 1.1, 1.2), a pattern consistent with shedding followed by in-situ burial. Notably, shedding of lateral segments during the ontogenetic sequence is common for living Dasycladales, the cytoplasm from these deciduous segments being retracted into the thallus before abscission commences (Berger and Kaever, 1992).

\section{Reproductive functional morphology}

In comparing Wiartonella with living dasycladalean algae, it is immediately obvious that the expanded terminations of the first-order lateral segments, referred to in this discussion generically as nodes to avoid unwarranted functional connotations, bear a resemblance to gametophores, at least superficially. In particular, the gametophores of Neomeris compare well in terms of size (diameter of $0.075-0.195 \mathrm{~mm}$ ) and position along the first-order lateral segment (terminal). The earliest dasycladalean with structures described as gametophores, and therefore proposed as choristospore according to the terminology of Pia (1920), is Kalania from the Llandoverian of Estonia (lower Silurian; Tinn et al., 2015). A gametophore identity for the illustrated structures, however, is equivocal. A stronger argument can be made for Uncatoella from the Lower Devonian of China (Kenrick and Li, 1998). Here, structures similar in size, shape, and position to the gametophores of the extant dasycladalean Batophora encapsulate unambiguous clusters of spherical objects comparable to the reproductive cysts of extant dasycladaleans, including the presence of an operculum.

For the nodes of Wiartonella, evidence of the sort necessary to definitively confirm or reject a gametophore identity is lacking. In particular, reproductive cysts are not evident anywhere within the thallus, even in scanning electron microscopy images taken in backscattered-electron mode, so that it cannot be determined that gametes occupied the nodes to the exclusion of other parts of the thallus. This is a key point because many extinct dasycladalean taxa lacked gametophores and, of these, some are known with certainty to have sequestered gametes within the main axis, such as Diplopora phanerospora (see Pia, 1920), or within the first-order laterals, such as Triploporella remesi and other triploporellids (reviewed in Barattolo et al., 2013), categorized, respectively, as endospore and cladospore by Pia (1920). In addition, although living dasycladalean algae are not known to produce laterals directly from the gametophores, an observation in keeping with the view that gametophores have a morphogenetic identity independent of the laterals (so that they are not simply modified lateral segments) (see Dumais and Harrison, 2000), current knowledge of dasycladalean morphogenesis is sufficiently incomplete that production of secondary lateral segments from the nodes of Wiartonella does not unequivocally eliminate the nodes-as-gametophores hypothesis. Finally, because thallus morphology for Wiartonella differs markedly from that of all well-established choristospore dasycladalean genera, it is not possible to establish a gametophore identity for the nodes on the basis of phylogenetic arguments. 

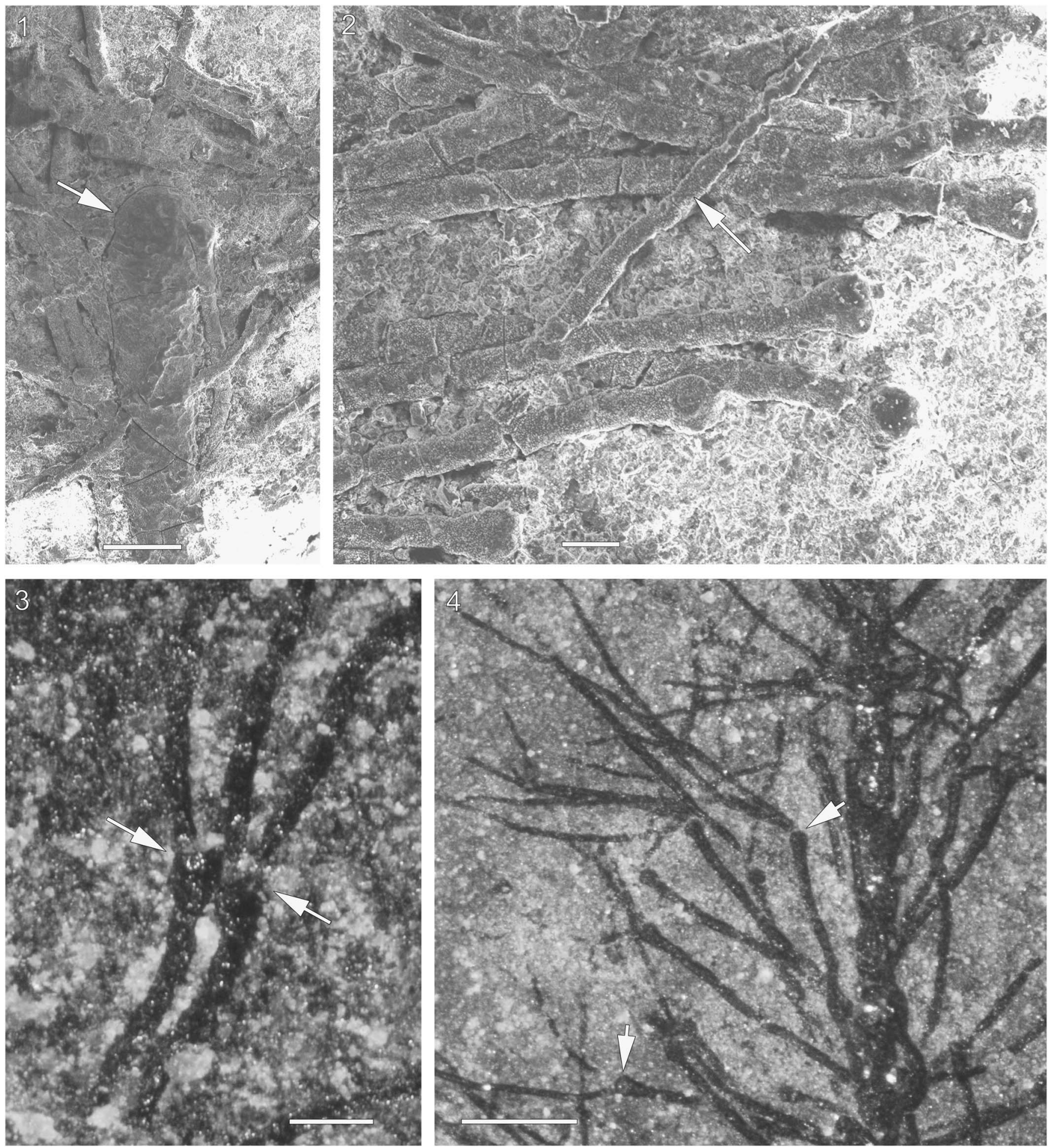

Figure 4. Morphological details of Wiartonella nodifera. $(\mathbf{1}, \mathbf{2})$ Scanning electron microscopy images of specimen shown in 3.9 (ROM 63803): (1) upper part of main axis showing 3D preservation and rounded apex (arrow); (2) primary lateral segments at upper right arrow in 3.9 showing cylindrical form and expanded terminations (nodes), a single detached second-order lateral segment with a tapered form (arrow) cuts diagonally across the image. (3) Photomicrograph of ROM 63804 (arrow in 3.1) showing expanded terminations of primary laterals (arrows) bearing pairs of secondary lateral segments, two of which overlap over much of their length near top center, specimen photographed dry in direct light. (4) Photomicrograph of ROM 63800 (arrow in 3.2) showing expanded terminations of primary laterals (arrows) bearing pairs of secondary lateral segments, specimen photographed under water. Scale bars are (1) $0.3 \mathrm{~mm} ;(\mathbf{2}) 0.1 \mathrm{~mm} ;(\mathbf{3}) 0.2 \mathrm{~mm} ;(\mathbf{4}) 1 \mathrm{~mm}$.

Although limitations noted above preclude definitive confirmation or rejection of the nodes-as-gametophores hypothesis, it should be possible to apply functional morphology, specifically biophysical modeling, to evaluate the effectiveness of these structures in such a role and thereby gain insights in this regard. Such an approach in this context is feasible because 


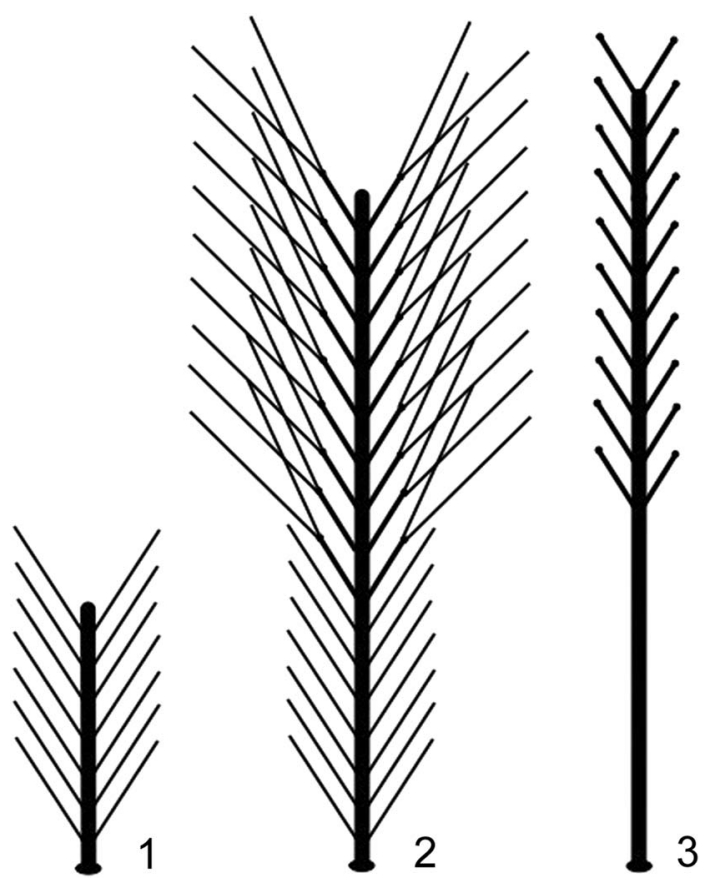

Figure 5. Schematic illustrations of Wiartonella nodifera thalli showing different ontogenetic stages: (1) stage 1 thallus with only unbranched hairlike laterals; (2) early stage 2 thallus with branched laterals; (3) late stage 2 thallus for which all second-order lateral segments have been shed. For simplicity, only two laterals per whorl are shown. See text for details.

dasycladalean algae reproduce through holocarpy, whereby essentially all of the cytoplasm from various parts of the thallus (main axis and lateral segments) streams into the reproductive structures and is devoted to reproduction, the thallus subsequently perishing. Detailed photographic documentation of this process is provided in Berger and Kaever (1992). Thus, for a given thallus, it is reasonable to infer that reproductive volume $(\mathrm{R})$, defined as the collective volume of thallus regions utilized for gamete containment, will approximately equal cytoplasm volume $(\mathrm{C})$. The latter, like reproductive volume, is a small subset of total interior thallus volume, in this case because most of the thallus interior in life is occupied by a large central vacuole, the cytoplasm forming only a thin film along the inner surface of the cell wall (Ngo et al., 2005) (Fig. 6.1). In basic outline this approach is similar to that used by Maksoud et al. (2014), but a key difference is that their study did not incorporate the central vacuole in calculations.

To evaluate whether the predicted relationship outlined above holds true for dasycladalean algae, biophysical modeling was applied to the extant species Dasycladus vermicularis, Neomeris dumetosa, and Cymopolia vanbosseae. For each, cytoplasm volume for a pre-reproductive whorl, including the gametophores, was modeled from aspects of external thallus morphology following the method described in LoDuca and Behringer (2009), and reproductive volume for the same whorl was calculated as the total interior volume of the gametophore, modeled as a sphere, multiplied by the number of gametophores developed on the whorl. Applying this approach to morphometric data for a single specimen of each species obtained from images in Berger and Kaever (1992) yielded C/R values for Dasycladus vermicularis, Neomeris dumetosa, and Cymopolia vanbosseae of 1.4, 1.8, and 1.7, respectively
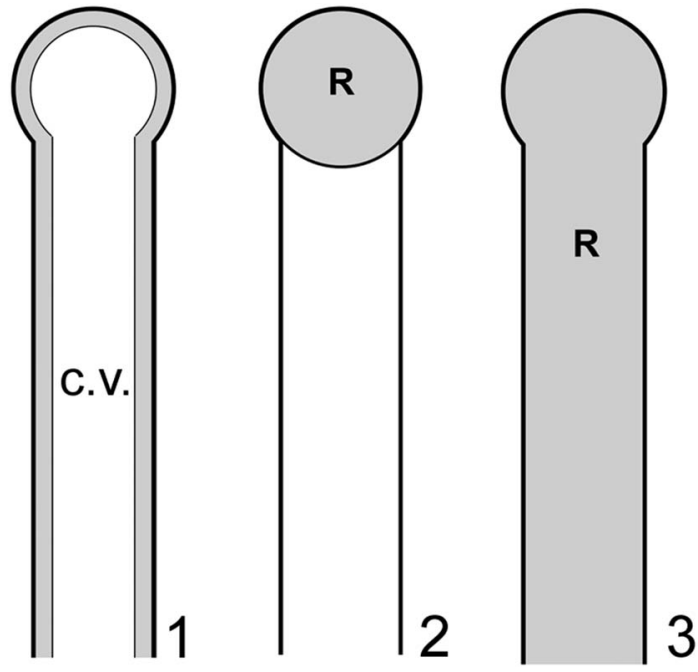

Figure 6. Models applied to investigate reproductive functional morphology for Wiartonella nodifera: (1) primary lateral in pre-reproductive state showing thin layer of cytoplasm (gray) along inner surface of cell wall and large central vacuole (white); (2) choristospore model, with node treated as a gametophore and filled with cytoplasm; (3) cladospore model, with entire primary lateral treated as a reproductive structure and filled with cytoplasm. Details of lateral morphology and cytoplasm thickness roughly to scale, but less than half of total length of primary lateral shown. $\mathrm{R}=$ reproductive volume; c.v. $=$ central vacuole.

(Table 2). Note that for the latter species, one-third of the cytoplasm volume from an associated "sterile" whorl was included in the total cytoplasm volume, since there are approximately three fertile whorls (i.e., whorls that develop gametophores) for every sterile whorl on the thallus of this species of Cymopolia (Berger and Kaever, 1992). Without cytoplasm input from the sterile whorls, each of which yielded a calculated cytoplasm volume roughly three times that of a fertile whorl, the C/R for this species falls to 0.8 , meaning that more reproductive volume would be produced than could be supplied by cytoplasm. For $D$. vermicularis and $N$. dumetosa, the same analyses were performed utilizing morphometric data presented in Maksoud et al. (2014). Using data from this source, the $\mathrm{C} / \mathrm{R}$ value calculated for $N$. dumetosa is comparable to that reported above (1.6 vs. 1.8; Table 2). For $D$. vermicularis, however, the resulting $\mathrm{C} / \mathrm{R}$ value differed by a factor of two (0.67 vs. 1.4). To explore this discrepancy, we collected morphometric data from an image of $D$. vermicularis in Berger (2006, fig. 82), the source utilized by Maksoud et al. (2014). Our measurements agree with those of Maksoud et al. (2014, table 8 ) in all regards except for width values associated with the secondand third-order laterals, which were larger by a factor of about two (Table 2). Incorporating our revised width measurements resulted in a $\mathrm{C} / \mathrm{R}$ value of 1.5 (Table 2). Collectively, the results provide compelling evidence that reproductive volume closely approximates cytoplasm volume for living dasycladalean algae, as predicted on theoretical grounds. That the calculated $\mathrm{C} / \mathrm{R}$ values are slightly above unity in each case is reasonable given that it is unlikely a thallus could stream all cytoplasm into the gametophores, a proposition supported by images in Berger and Kaever (1992) which show some remnant cytoplasm adhering to the inner cell walls of all reproductively mature specimens. In general, there is no reason to think that a similar C/R relationship should not apply to extinct taxa and, crucially, it is possible to apply this approach to well-preserved fossil specimens. 
Table 2. Morphometric data and modeled values of cytoplasm volume (C), reproductive volume (R), and C/R for a single reproductive whorl of three species of extant dasycladalean algae: (1) Dasycladus vermicularis, (2) Neomeris dumetosa, and (3) Cymopolia vanbosseae. Morphometric measurements obtained from images in Berger and Kaever (1992, figs. 3.38, 3.45, 3.7) and Berger (2006, fig. 82), and from table 9 in Maksoud et al. (2014). All morphometric measurements in millimeters. $\mathrm{C}$ and $\mathrm{C} / \mathrm{R}$ values for Cymopolia vanbosseae include $\mathrm{C}$ from an associated sterile whorl (see text). $1=$ length of lateral segment; $\mathrm{r}=$ radius of lateral segment; $\mathrm{N}=$ number of lateral segments per whorl; $\mathrm{g}=$ gametophore radius; $\mathrm{gN}=$ number of gametophores per whorl.

\begin{tabular}{|c|c|c|c|c|c|c|c|c|c|c|c|c|c|c|c|}
\hline Species & Source & $l_{1}$ & $\mathrm{r}_{1}$ & $\mathrm{~N}_{1}$ & $l_{2}$ & $r_{2}$ & $\mathrm{~N}_{2}$ & $1_{3}$ & $r_{3}$ & $\mathrm{~N}_{3}$ & $\mathrm{~g}$ & $\mathrm{gN}$ & $\mathrm{C} \mathrm{mm}^{3}$ & $\mathrm{R} \mathrm{mm}^{3}$ & $\mathrm{C} / \mathrm{R}$ \\
\hline 1 & fig. 3.7 & 0.80 & 0.075 & 12 & 0.50 & 0.050 & 48 & 0.25 & 0.025 & 192 & 0.14 & 12 & 0.170 & 0.124 & 1.4 \\
\hline 2 & fig. 3.38 & 0.38 & 0.025 & 30 & 0.25 & 0.018 & 60 & - & 0.046 & 60 & 0.06 & 30 & 0.037 & 0.021 & 1.8 \\
\hline 2 & table 9 & 0.36 & 0.020 & 28 & 0.22 & 0.015 & 56 & - & 0.050 & 56 & 0.06 & 28 & 0.033 & 0.021 & 1.6 \\
\hline
\end{tabular}

To evaluate the nodes of Wiartonella as gametophores (choristospore hypothesis; Fig. 6.2), as a first pass, R was modeled as total node volume within a whorl, with nodes approximated as spheres, and $\mathrm{C}$ was modeled as cytoplasm volume exclusively for the first-order lateral segments of the same whorl. Results indicate a $\mathrm{C} / \mathrm{R}$ value of 3.5 for a whorl with values of lateral length, lateral diameter, and node diameter equivalent to those of the holotype, ROM 63795 (Fig. 3.3) (model 1 in Table 3). For five other specimens modeled in this way, $C / R$ values are similar, ranging from a low of 3.5 to a high of 4.7 (avg. 3.95) (Table 3). Note that although modeling of $\mathrm{C}$ and $\mathrm{R}$ was conducted using 12 laterals per whorl, the number of laterals per whorl is irrelevant from the perspective of the $C / R$ value in this case, because node number and first-order lateral number per whorl are equivalent. Thus, the fact that $\mathrm{C}$ is substantially greater than R for Wiartonella when modeled in this way is entirely a consequence of the node being quite small relative to the preceding cylindrical portion of the lateral, the latter being many times longer and over half as wide as the node in all cases (Table 1). Considered more holistically, the difference between $\mathrm{C}$ and $\mathrm{R}$ is even greater, because $\mathrm{C}$ must also include cytoplasm volume from the associated second-order lateral segments (two for each first-order segment). When this factor is included, the resulting cytoplasm volume calculated for the various specimens is roughly an order of magnitude greater than the associated reproductive volume (model 2 in Table 3 ). Such a relationship casts considerable doubt on the possibility of homology between gametophores and the nodes of Wiartonella, because it would entail that most of the thallus cytoplasm (i.e., $>90 \%$ ) was not used for reproduction.

Interestingly, modeling of the same nature, but treating the entire first-order lateral segment of Wiartonella as a reproductive structure (cladospore hypothesis; Fig. 6.3), yields $\mathrm{C} / \mathrm{R}$ values comparable to those calculated herein for extant taxa. For example, when $\mathrm{R}$ is modeled in this way for the holotype, the $\mathrm{C} / \mathrm{R}$ value is 1.7 , where $\mathrm{C}$ includes cytoplasm from the second-order lateral segments, and for the other specimens, $\mathrm{C} / \mathrm{R}$ values modeled in the same way fall within a narrow range between 1.6 and 2.0 (model 3 in Table 3). Such an outcome provides strong support for the cladospore hypothesis. Nonetheless, cladospore reproduction for Wiartonella cannot be definitively established. Apart from lacking evidence of reproductive cysts (to mark the location of gamete containment), uncertainty arises because modeling indicates $C / R$ values for endospore reproduction (where the entire main axis interior serves as $\mathrm{R}$ and $\mathrm{C}$ is determined by total thallus cytoplasm volume) not much different from those for cladospore reproduction. For example, for the holotype, the modeled $\mathrm{C} / \mathrm{R}$ value for endospore
Table 3. Modeled values of cytoplasm volume $(\mathrm{C})$, reproductive volume $(\mathrm{R})$, and $\mathrm{C} / \mathrm{R}$ for specimens of Wiartonella nodifera using morphometric data from Table 1. Values pertain to a single fertile whorl with 12 laterals per whorl. Model parameters as follows: (1) R calculated for node only, $\mathrm{C}$ excludes second-order lateral segments; (2) R calculated for node only, C includes second-order lateral segments; (3) R calculated for entire first-order lateral segment, including node, $\mathrm{C}$ includes second-order lateral segments. See text for additional details.

\begin{tabular}{lcccr}
\hline Specimen & Model & $\mathrm{C} \mathrm{mm}^{3}$ & $\mathrm{R} \mathrm{mm}^{3}$ & $\mathrm{C} / \mathrm{R}$ \\
\hline ROM 63792 & 1 & 0.0274 & 0.0063 & 4.3 \\
ROM 63795 & 1 & 0.0217 & 0.0063 & 3.5 \\
ROM 63796.1 & 1 & 0.0324 & 0.0084 & 3.9 \\
ROM 63800 & 1 & 0.0175 & 0.0046 & 3.8 \\
ROM 63803 & 1 & 0.0297 & 0.0063 & 4.7 \\
ROM 63804 & 1 & 0.0160 & 0.0046 & 3.5 \\
ROM 63792 & 2 & 0.0787 & 0.0063 & 12.5 \\
ROM 63795 & 2 & 0.0649 & 0.0063 & 10.3 \\
ROM 63800 & 2 & 0.0511 & 0.0046 & 11.1 \\
ROM 63804 & 2 & 0.0525 & 0.0046 & 11.4 \\
ROM 63792 & 3 & 0.0787 & 0.0501 & 1.6 \\
ROM 63795 & 3 & 0.0649 & 0.0376 & 1.7 \\
ROM 63800 & 3 & 0.0511 & 0.0281 & 1.8 \\
ROM 63804 & 3 & 0.0525 & 0.0258 & 2.0 \\
\hline
\end{tabular}

reproduction is 1.8. Thus, results of biophysical modeling provide no clear distinction between cladospore and endospore reproduction for Wiartonella. Beyond the distinctive form of the first-order laterals, however, the ontogeny of Wiartonella provides additional support for the cladospore hypothesis, because late in thallus ontogeny the second-order lateral segments were shed but the first-order laterals remained attached. It is also notable in this regard that a few main axes have been found with few or no firstorder laterals (Fig. 2.11, 2.12). This suggests that these, too, were eventually shed, during a separate and later shedding event. Such a fate is also known for the reproductive structures of some living dasycladalean taxa, perhaps to aid in dispersal of the gametes while still in a protected state.

\section{Evolutionary significance}

Regarded as either endospore or cladospore, Wiartonella is accommodated within the family Triploporellaceae, which comprises euspondyl taxa with either endospore or cladospore reproduction (LoDuca, 1997; Granier et al., 2012). If the euspondyl condition evolved only once in the evolutionary history of Dasycladales, which seems a reasonable proposition given the available evidence, then all euspondyl taxa comprise a single clade and the extinct Triploporellaceae is paraphyletic to extant Dasycladaceae and Polyphysaceae (Kenrick and Li, 1998; LoDuca et al., 2003). Within the Triploporellaceae, the lack of a cortex and the presence of two orders of laterals indicate placement within the tribe Triploporelleae, and the inflated nature of the first-order 
lateral segments together with a likely reproductive role for these segments, as indicated by modeling and ontogeny, points to placement within the subtribe Triploporellinae (see Deloffre, 1988). The phylogenetic significance of these taxa remains to be investigated, but so considered Wiartonella becomes the oldest member of both the tribe and subtribe, the next oldest members being calcified taxa of late Paleozoic age, as well as an early member of a putative lineage that includes the Mesozoic cladospore taxon Triploporella. It is possible that Kalania should be placed in the Triploporellinae as well, given that all aspects of lateral morphology and arrangement are consistent with such an assignment and the ovate objects labeled as gametophores in Tinn et al. (2015) would seem to leave room for alternative interpretations, in part because they are not shown to be in unequivocal anatomical contact with other thallus elements. Perhaps most importantly in evolutionary terms, the development of laterals with distinctly inflated terminations and euspondyl arrangement in both Wiartonella and cyclocrinitids suggests the possibility that these early Paleozoic macroalgae are rooted in a close common ancestor.

\section{Acknowledgments}

The late H. Stobbe and his children, L. Grimoldby and T. Stobbe, of Owen Sound Ledgerock Ltd., provided valuable access and assistance during fieldwork, without which this study would not have been possible. E. Behringer provided assistance with the biophysical modeling component of the project, and comparisons with fossil Dasycladales were aided by discussions with F. Barattolo. J. Schiffbauer kindly assisted with scanning electron microscopy analyses and provided the EDS image. The final manuscript was improved by comments provided by B. Granier and an anonymous reviewer; the associate editor, R. Lupia; and the editor, J. Jin. This project was partially funded by NSF EAR 1250756 awarded to S.L. D.T. would also like to thank A. Lenz as advisor for the doctoral project during which Wiartonella was discovered and initially studied, partially funded by an NSERC Operating Grant to Lenz.

\section{References}

Armstrong, D.K., 1993, Paleozoic geology of the central Bruce Peninsula: Ontario Geological Survey Open File Report 5856, 19 p.

Bancroft, A.M., Kleffner, M.A., and Brunton, F.R., 2016, Biochemostratigraphy of the Eramosa Formation in southwestern Ontario, Canada: Canadian Journal of Earth Sciences, v. 53, p. 749-762.

Barattolo, F., Cozzi, A., and Romano, R., 2008, New dasycladalean algae from the Middle Norian (Upper Triassic) of northern Italy (Mt. Pramaggiore, Carnic Prealps): Facies, v. 54, p. 549-580.

Barattolo, F., Bucur, I.I., Kołodziej, B., Hoffmann, M., and Skupien, P., 2013, Triploporella remesi (Steinmann, 1903), dasycladalean green alga from the Tithonian-Lower Berriasian of Stramberk (Czech Republic) revisited: Facies, v. 59, p. 179-191.

Bassoullet, J.P., Bernier, P., Deloffre, R., Génot, P., Jaffrezo, M., and Vachard, D., 1979, Essai de classification des Dasycladales en tribus: Bulletin des Centres de Recherches Exploration-Production Elf-Aquitaine, v. 3, p. 429-442.

Berger, S., 2006, Photo-Atlas of living Dasycladales: Carnets de Géologie, Brest, $348 \mathrm{p}$.

Berger, S., and Kaever, M.J., 1992, Dasycladales: An Illustrated Monograph of a Fascinating Algal Order: Stuttgart, Georg Thieme, $247 \mathrm{p}$.

Bernier, P., 1979, Le genre Petrascula Gümbel 1873, algue dasycladacée: émendation, révision des espèces du genre, création de nouvelles espèces: Geobios, v. 12, p. 839-861.
Brett, C.E., Tepper, D.H., Goodman, W.M., LoDuca, S.T., and Eckert, B.-Y 1995, Revised stratigraphy and correlations of the Niagaran provincial series (Medina, Clinton, and Lockport groups) in the type area of western New York: U.S. Geological Survey Bulletin, v. 2086, p. 1-66.

Collette, J.H., and Rudkin, D.M., 2010, Phyllocarid crustaceans from the Silurian Eramosa Lagerstätte (Ontario, Canada): taxonomy and functional morphology: Journal of Paleontology, v. 84, p. 118-127.

Deloffre, R., 1988, Nouvelle taxonomie des algues Dasycladales: Bulletin des Centre de Recherches Exploration-Production Elf-Aquitaine, v. 12, p. $165-217$

Dumais, J., and Harrison, L.G., 2000, Whorl formation in the dasycladalean algae: the pattern formation viewpoint: Philosophical Transactions of the Royal Society of London B, v. 161, p. 281-305.

Eriksson, M.E., and von Bitter, P.H., 2015, Jaw-bearing polychaetes of the Silurian Eramosa Lagerstätte, Ontario, Canada: Journal of Paleontology, v. 89 , p. 222-235.

Feist, M., Génot, P., and Grambast-Fessard, N., 2003, Ancient Dasycladales and Charophyta: Convergences and differences, with special attention to Munieria baconica: Phycologia, v. 42, p. 123-132.

Granier, B., Dias-Brito, D., Bucur, I.I., and Tibana, P., 2012, Brasiliporella, a new mid-Cretaceous dasycladacean genus: the earliest record of the Tribe Batophoreae: Facies, v. 59, p. 207-220.

Gümbel, C.W., 1872, Die sogenannten Nulliporen (Lithothamnium und Dactylopora) und ihre Betheiligung an der Zusammensetzung der Kalkgesteine. Zweiter Theil: Die Nulliporen des Thierreichs (Dactyloporideae) nebst Nachtrag zum ersten Theile: Abhandlungen der Mathematisch-Physikalischen Classe der Königlich Bayerischen Akademie der Wissenschaften, v. XI, p. 231-290.

Gümbel, C.W., 1873, Ueber Conodictyum bursiforme Etallon, eine Foraminifere aus der Gruppe der Dactyloporideen: Sitzungsberichte der Kaiserlichen und Königlichen Akademie der Wissenschaften Wien, MathematischNaturwissenschaftliche, v. III, p. 282-294.

Kenrick, P., and Li, C.-S., 1998, An early, non-calcified dasycladalean alga from the Lower Devonian of Yunnan Province, China: Review of Palaeobotany and Palynology, v. 100, p. 73-88.

Kenrick, P., and Vinther, J., 2006, Chaetocladus gracilis n. sp., a non-calcified Dasycladales from the Upper Silurian of Skåne, Sweden: Review of Palaeobotany and Palynology, v. 142, p. 153-160.

LoDuca, S.T., 1990, Medusaegraptus mirabilis as a noncalcified dasyclad alga: Journal of Paleontology, v. 64, p. 469-474.

LoDuca, S.T., 1995, Thallophytic-alga-dominated biotas from the Silurian Lockport Group of New York and Ontario: Northeastern Geology and Environmental Sciences, v. 17, p. 371-383.

LoDuca, S.T., 1997, The green alga Chaetocladus (Dasycladales): Journal of Paleontology, v. 71, p. 940-949.

LoDuca, S.T., and Behringer, E.R., 2009, Functional morphology and evolution of early Paleozoic dasycladalean algae: Paleobiology, v. 35, p. 63-76.

LoDuca, S.T., Kluessendorf, J., and Mikulic, D.G., 2003, A new noncalcified dasycladalean alga from the Silurian of Wisconsin: Journal of Paleontology, v. 77, p. 956-962.

LoDuca, S.T., Melchin, M., and Verbruggen, H., 2011, Complex noncalcified macroalgae from the Silurian of Cornwallis Island, Arctic Canada: Journal of Paleontology, v. 85, p. 111-121.

LoDuca, S., Miller, R., and Wilson, R., 2013, Medusaegraptus (Chlorophyta, Dasycladales) from the Pridolian to middle Lochkovian Indian Point Formation, New Brunswick, Canada: Atlantic Geology, v. 49, p. 118-125.

Maksoud, S., Granier, B., and Azar, D., 2014, First record of Harlanjohnsonella annulata Elliott in Granier et Deloffre, 1993, non 1968, a Triploporellacean alga in Late Barremian-earliest Bedoulian strata of Lebanon: Acta Palaeontologica Romaniae, v. 10, p. 47-60.

Mastik, V., and Tinn, O., 2015, New dasycladalean algal species from the Kalana Lagerstätte (Silurian, Estonia): Journal of Paleontology, v. 89, p. 262-268.

Ngo, D.A., Garland, P.A., and Mandoli, D.F., 2005, Development and organization of the central vacuole of Acetabularia acetabulum: New Phytologist, v. 165 , p. $731-746$.

Pascher, A., 1931, Systematische Übersicht über die mit Flagellaten in Zusammenhang stehenden Algenreihen und Versuch einer Einreihung dieser Algenstamme in die Stämme des Pflanzenreiches: Botanisches Centralblatt, Beiheft, v. 48, p. 317-332.

Pia, J., 1920, Die Siphoneae verticillatae vom Karbon bis zur Kreide: Abhandlungender Zoologisch-Botanischen Gesellschaftin Wien, v. 11, p. $1-263$.

Pia, J., 1925, Einige neue oder ungenügend bekannte Siphoneae verticillatae aus dem mitteleuropäischen Malm: Annalen des Naturhistorischen Museums in Wien, v. 38, p. $82-88$.

Pia, J., 1930, Upper Triassic fossils from the Burmo-Siamese frontier: A new Dasycladacea, Holosporella siamensis nov. gen., nov. sp., with a description of the allied genus Aciculella Pia: Records of the Geological Survey of India, v. 63, p. 177-181. 
Steinmann, C., 1880, Zur Kenntnis fossiler Kalkalgen (Siphoneen): Neues Jahrbuch für Mineralogie, Geologie und Paläontologie, v. 2, p. $130-140$.

Stolley, E., 1893, Uber Silurische Siphoneen: Neues Jahrbuch für Mineralogie, Geologie und Paläontologie, v. 2, p. 135-146.

Tetreault, D.K., 1995, An unusual Silurian arthropod/echinoderm dominated soft-bodied fauna from the Eramosa Member (Ludlow) of the Guelph Formation, southern Bruce Peninsula, Ontario, Canada: Geological Society of America Abstracts with Programs, v. 27, p. 114.

Tetreault, D.K., 2001, A new Silurian Konservat- Lagerstätte from the Eramosa Dolostone of the southern Bruce Peninsula, Ontario, Canada [Ph.D. thesis]: London, University of Western Ontario, $194 \mathrm{p}$.

Tinn, O., Meidla, T., Ainsaar, L., and Pani, T., 2009, Thallophytic algal flora from a new Silurian Lagerstätte: Estonian Journal of Earth Sciences, v. 58, p. $38-42$.
Tinn, O., Mastik, V., Ainsaar, L., and Meidla, T., 2015, Kalania pusilla, an exceptionally preserved non-calcified alga from the lower Silurian (Aeronian, Llandovery) of Estonia: Palaeoworld, v. 24, p. 207-214.

von Bitter, P.H., Purnell, M.A., Tetreault, D.K., and Stott, C.A., 2007, Eramosa Lagerstätte - Exceptionally preserved soft-bodied biotas with shallowmarine shelly and bioturbating organisms (Silurian, Ontario, Canada): Geology, v. 35, p. 879-882.

Yabe, H., and Toyama, S., 1949, New Dasycladaceae from the Jurassic Torinosu Limestone of the Sakawa Basin, Sikoku: Proceedings of the Japan Academy, v. 25, p. 160-164.

Accepted 2 September 2016 